Article

\title{
Primary Mode of Action of the Novel Sulfonamide Fungicide against Botrytis cinerea and Field Control Effect on Tomato Gray Mold
}

\author{
Xiaojing Yan ${ }^{1} \mathbb{D}$, Shuning Chen ${ }^{1} \mathbb{D}$, Wei Sun ${ }^{1}$, Xiaoxin Zhou ${ }^{1}$, Daibin Yang ${ }^{1}$, Huizhu Yuan ${ }^{1, *}$ \\ and Daoquan Wang ${ }^{2, *}$
}

1 Institute of Plant Protection, Chinese Academy of Agricultural Sciences, No. 2 Yuanmingyuan West Road, Haidian District, Beijing 100193, China; yanxiaojing@caas.cn (X.Y.); chenshuning@caas.cn (S.C.); 82101205222@caas.cn (W.S.); m13898156865@163.com (X.Z.); yangdaibin@caas.cn (D.Y.)

2 Department of Applied Chemistry, China Agricultural University, No. 2 Yuanmingyuan West Road, Haidian District, Beijing 100193, China

* Correspondence: hzhyuan@caas.cn (H.Y.); wangdq@cau.edu.cn (D.W.); Tel.: +86-10-6281-5941 (H.Y.); +86-10-6273-1901 (D.W.)

\section{check for}

updates

Citation: Yan, X.; Chen, S.; Sun, W.; Zhou, X.; Yang, D.; Yuan, H.; Wang, D. Primary Mode of Action of the Novel Sulfonamide Fungicide against Botrytis cinerea and Field Control Effect on Tomato Gray Mold. Int. J. Mol. Sci. 2022, 23, 1526. https:// doi.org/10.3390/ijms23031526

Academic Editors: Makoto Kimura, Dejan Stojković, Marija Ivanov and Ana Ćirić

Received: 13 December 2021

Accepted: 26 January 2022

Published: 28 January 2022

Publisher's Note: MDPI stays neutral with regard to jurisdictional claims in published maps and institutional affiliations.

Copyright: (C) 2022 by the authors. Licensee MDPI, Basel, Switzerland. This article is an open access article distributed under the terms and conditions of the Creative Commons Attribution (CC BY) license (https:// creativecommons.org/licenses/by/ $4.0 /)$.

\begin{abstract}
Botrytis cinerea is considered an important plant pathogen and is responsible for significant crop yield losses. With the frequent application of commercial fungicides, $B$. cinerea has developed resistance to many frequently used fungicides. Therefore, it is necessary to develop new kinds of fungicides with high activity and new modes of action to solve the increasingly serious problem of resistance. During our screening of fungicide candidates, one novel sulfonamide compound, $N$-(2-trifluoromethyl-4-chlorphenyl)-2-oxocyclohexyl sulfonamide (L13), has been found to exhibit good fungicidal activity against $B$. cinerea. In this work, the mode of action of L13 against $B$. cinerea and the field control effect on tomato gray mold was studied. L13 had good control against B. cinerea resistant to carbendazim, diethofencarb, and iprodione commercial fungicides in the pot culture experiments. SEM and TEM observations revealed that L13 could cause obvious morphological and cytological changes to B. cinerea, including excessive branching, irregular ramification or abnormal configuration, and the decomposition of cell wall and vacuole. L13 induced more significant electrolyte leakage from hyphae than procymidone as a positive control. L13 had only a minor effect on the oxygen consumption of intact mycelia, with $2.15 \%$ inhibition at $50 \mu \mathrm{g} / \mathrm{mL}$. In two locations over 2 years, the field control effect of $\mathbf{L} 13$ against tomato gray mold reached $83 \%$ at a rate of $450 \mathrm{~g}$ ai $\mathrm{ha}^{-1}$, better than the commercial fungicide of iprodione. Moreover, toxicological tests demonstrated the low toxicological effect of L13. This research seeks to provide technical support and theoretical guidance for $\mathbf{L 1 3}$ to become a real commercial fungicide.
\end{abstract}

Keywords: sulfonamide fungicide; Botrytis cinerea; mode of action; field control; tomato gray mold

\section{Introduction}

Botrytis cinerea Pers ex Fr (teleomorph: Botryotinia fuckeliana) is one of the most commonly studied polyphagous fungal plant pathogens, causing gray mold on more than 1400 known hosts in 586 plant genera and 152 botanical families worldwide [1,2]. Due to both its scientific and economic importance, $B$. cinerea is considered among the most important plant pathogens and is responsible for significant crop yield losses [3]. To date, the principal strategy to control gray mold rot caused by $B$. cinerea has been to rely on chemical control through the application of synthetic fungicides [4]. Most of the registered fungicides to control gray mold are quinone outside inhibitors, benzimidazole, carbamates, phenylpyrroles, and succinate dehydrogenase inhibitors [5]. However, because of its host diversity, prolific reproduction, short life cycle, and high genetic variability, during the past decades, many strains of $B$. cinerea with multiple resistance to conventional fungicides 
have appeared on various crops worldwide [5-7]. Fungicide resistance in B. cinerea has unquestionably resulted in the decreased efficacy and even failure of the chemical control of gray mold. Therefore, it is necessary to develop new kinds of fungicides with high activity and new modes of action to solve the increasingly serious problem of resistance.

Among the plethora of various unique chemical structures, sulfonamides, the most common scaffolds in sulfur-containing molecules, have received considerable attention from all walks of life due to their eminent biological activities and serve an important function in the pharmaceutical industry $[8,9]$. In addition to medical applications, sulfonamides have also been registered as commercial pesticides (e.g., fungicides of flusulfamide, tolnifanide, cyazofamid, and amisulbrom, herbicides of pyroxsulam and penoxsulam, and the insecticide of fluorosulamid) and developed as pesticide candidates [10-13]. These results clearly demonstrate that developing sulfonamide pesticides with new structures and mechanisms is still highly desirable and promising. According to the pesticide registration information, only cyazofamid and amisulbrom have been registered and used in China [14]. Amisulbrom has been registered as a single fungicide. Cyazofamid has been widely used as a single fungicide or combined with other fungicides, including dimethomorph, fluopicolide, famoxadone, and pyraclostrobin [14].

During the screening of fungicide candidates, a series of sulfonamides with different scaffolds have been designed and synthesized with moderate to good fungicidal activities [15-20]. Among the sulfonamides developed by our group, N-(2-trifluoromethyl-4chlorphenyl)-2-oxocyclohexyl sulfonamide (L13, generic name chesulfamide, codename CAUWL-2004-L-13, CAS No. 925234-67-9) (Figure 1) exhibited a broad spectrum of fungicidal activity and especially good fungicidal activity against $B$. cinerea with the $\mathrm{EC}_{50}$ of $2.12 \mu \mathrm{g} / \mathrm{mL}$, comparable with the commercial fungicide procymidone (the $\mathrm{EC}_{50}$ value is $2.45 \mu \mathrm{g} / \mathrm{mL}$ ) [18,21]. However, the mode of action of $\mathbf{L 1 3}$ against $B$. cinerea is not clear, which deserves further investigation to be a commercial fungicide. Furthermore, the superior fungicidal activity against $B$. cinerea must be verified through pot culture and field efficacy trials.

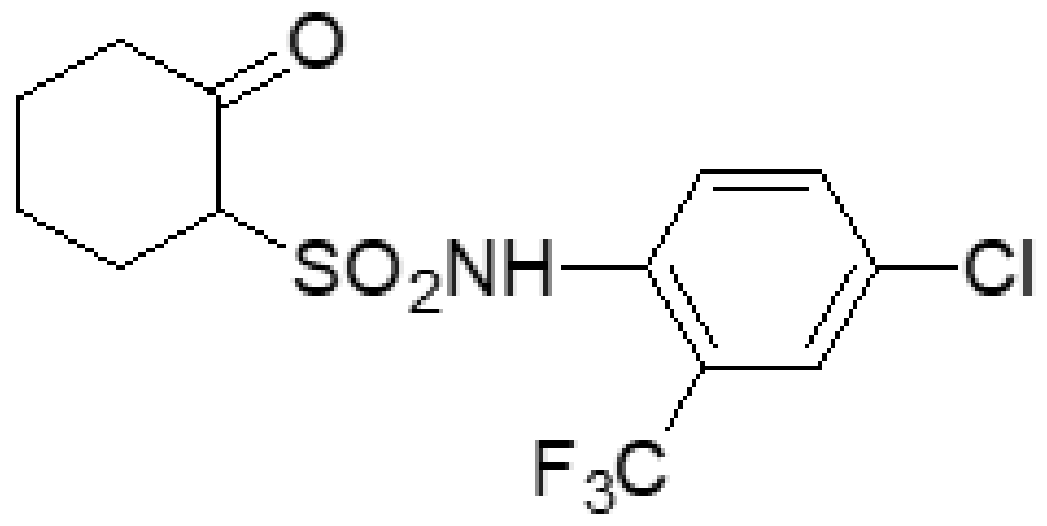

Figure 1. The chemical structure of L13.

In this work, the antifungal activity of L13 against $B$. cinerea strains on tomatoes resistant to commercial fungicides has been studied. To elucidate the mode of action of L13 against $B$. cinerea, the effects of L13 on the ultrastructural of hyphae, electrolyte leakage, and respiration of mycelia suspension were explored. Furthermore, the evaluation of L13 to control tomato gray mold (B. cinerea) through field efficacy trials and evaluation of the toxicology profile were reported. This research seeks to provide technical support and theoretical guidance for L13 to become a real commercial fungicide. 


\section{Results and Discussion}

\subsection{Control Effect of L13 against B. cinerea Resistant to Commercial Fungicides}

As mentioned above, with the frequent application of commercial fungicides, B. cinerea has developed resistance to many used fungicides under selective pressure. Thus, research and development of new fungicides with a new mode of action is highly desirable. In the present study, the control effect of L13 against $B$. cinerea resistant to commercial fungicides of carbendazim, diethofencarb, and iprodione was investigated. Carbendazim is a widely-used broad-spectrum fungicide that inhibits mitotic microtubule formation and cell division [22], and the evolution of the resistance of B. cinerea to carbendazim in recent years has appeared [23]. Diethofencarb belongs to $N$-phenylcarbamates and can result in scattered nuclei and inhibited mitotic nuclear division [24], and has also developed resistance to $B$. cinerea in some regions [25]. Iprodione is an effective broad-spectrum, contact-type dicarboximide fungicide, commonly used to control early deciduous disease, inhibiting protein kinases and interfering with the intracellular signals of multiple cellular functions [26]. A study on the control effect of L13 against B. cinerea is helpful to understand the mode of action and could provide a potential alternative to address the developed resistance of $B$. cinerea to these presently used commercial fungicides.

As shown in Table 1, the test fungicide, L13, gave good control against $B$. cinerea resistant to commercial fungicides of carbendazim, diethofencarb, and iprodione in the pot culture experiments. The control effect of $\mathbf{L 1 3}$ against $B$. cinerea resistant to carbendazim reached $81.36 \%$ at a rate of $187.5 \mathrm{~g}$. ai ha ${ }^{-1}$, and was better than carbendazim at a rate of 750 g. ai ha ${ }^{-1}(29.00 \%)$. The control effect of $\mathbf{L 1 3}$ against $B$. cinerea resistant to diethofencarb reached $92.61 \%$ at a rate of $187.5 \mathrm{~g}$. ai ha ${ }^{-1}$, and was better than diethofencarb at a rate of 267.9 g. ai ha ${ }^{-1}(76.36 \%)$. The control effect of L13 against B. cinerea resistant to iprodione reached $78.27 \%$ at a rate of $187.5 \mathrm{~g}$. ai ha ${ }^{-1}$, and was much better than iprodione at a rate of $375 \mathrm{~g}$. ai ha ${ }^{-1}(2.36 \%)$. These results suggested that $\mathbf{L} 13$ had a good control effect against $B$. cinerea and had no cross-resistance with the commercial fungicides carbendazim, diethofencarb, and iprodione.

Table 1. Control effect of L13 against B. cinerea resistant to commercial fungicides.

\begin{tabular}{|c|c|c|c|c|c|}
\hline \multirow{2}{*}{ Strains ${ }^{a}$} & \multirow{2}{*}{ Treatment } & \multicolumn{2}{|c|}{ Dosage } & \multirow{2}{*}{ Disease Area (mm) } & \multirow{2}{*}{ Control Effect (\%) } \\
\hline & & Dilution Multiple $^{\mathbf{b}}$ & g.ai ha ${ }^{-1}$ & & \\
\hline \multirow{6}{*}{ HM-1 } & \multirow{2}{*}{ L13 25\%WP } & 1000 & 187.5 & 37.09 & $81.36 \mathrm{c}$ \\
\hline & & 2000 & 93.75 & 72.87 & $63.38 \mathrm{~d}$ \\
\hline & Carbendazim 50\% WP & 500 & 750 & 141.29 & $29.00 \mathrm{e}$ \\
\hline & Diethofencarb 50\% WP & 1400 & 267.9 & 0.55 & $99.72 \mathrm{a}$ \\
\hline & Iprodione 50\% WP & 1000 & 375 & 15.88 & $92.02 \mathrm{~b}$ \\
\hline & control & - & - & 199.01 & - \\
\hline \multirow{6}{*}{ HM-2 } & \multirow{2}{*}{ L13 25\%WP } & 1000 & 187.5 & 13.11 & $92.61 \mathrm{~b}$ \\
\hline & & 2000 & 93.75 & 46.57 & $73.76 \mathrm{~d}$ \\
\hline & Carbendazim $50 \% \mathrm{WP}$ & 500 & 750 & 1.79 & 98.99 a \\
\hline & Diethofencarb 50\% WP & 1400 & 267.9 & 41.96 & $76.36 \mathrm{c}$ \\
\hline & Iprodione $50 \% \mathrm{WP}$ & 1000 & 375 & 2.16 & 98.78 a \\
\hline & control & - & - & 177.51 & - \\
\hline \multirow{5}{*}{ HM-3 } & \multirow{2}{*}{ L13 25\%WP } & 1000 & 187.5 & 6.26 & $78.27 \mathrm{a}$ \\
\hline & & 2000 & 93.75 & 19.43 & $32.56 \mathrm{c}$ \\
\hline & Diethofencarb 50\% WP & 1400 & 267.9 & 11.64 & $59.60 \mathrm{~b}$ \\
\hline & Iprodione $50 \% \mathrm{WP}$ & 1000 & 375 & 28.13 & $2.36 \mathrm{~d}$ \\
\hline & control & - & - & 28.81 & - \\
\hline
\end{tabular}

${ }^{a}$ HM-1 strains for B. cinerea resistant to carbendazim; HM-2 strains for B. cinerea resistant to diethofencarb; HM-3 strains for $B$. cinerea resistant to iprodione. ${ }^{b}$ Dilution multiple means the volume of water $(\mathrm{mL})$ used per unit mass (g) of a pesticide formulation. ${ }^{c}$ Different letters $(\mathrm{a}, \mathrm{b}, \mathrm{c}, \mathrm{d})$ are significantly different according to Duncan's multiple range test $(p=0.05)$. 


\subsection{The Mode of Action of L13 against B. cinerea}

2.2.1. Effect of L13 on Morphology and Ultrastructure Transformation of B. cinerea

To investigate the mechanism by which $\mathbf{L} 13$ affects the growth of $B$. cinerea, SEM and TEM were employed to examine the structural changes of mycelia after L13 treatment. SEM images of the mycelia grown on the PDA without L13 are shown in Figure 2. The mycelia were low density, fresh, and had a fine structure (Figure 2A). The interval between the two septa in hypha was relatively large (Figure 2B). The hyphae had a lot of branches that had a uniform distribution, and the surface of the hypha surface was evenly smooth (Figure 2C,D). The structure of the tip of the hypha and the septa were normal (Figure 2E-G). All of these images contain typical characteristics of B. cinerea [27].
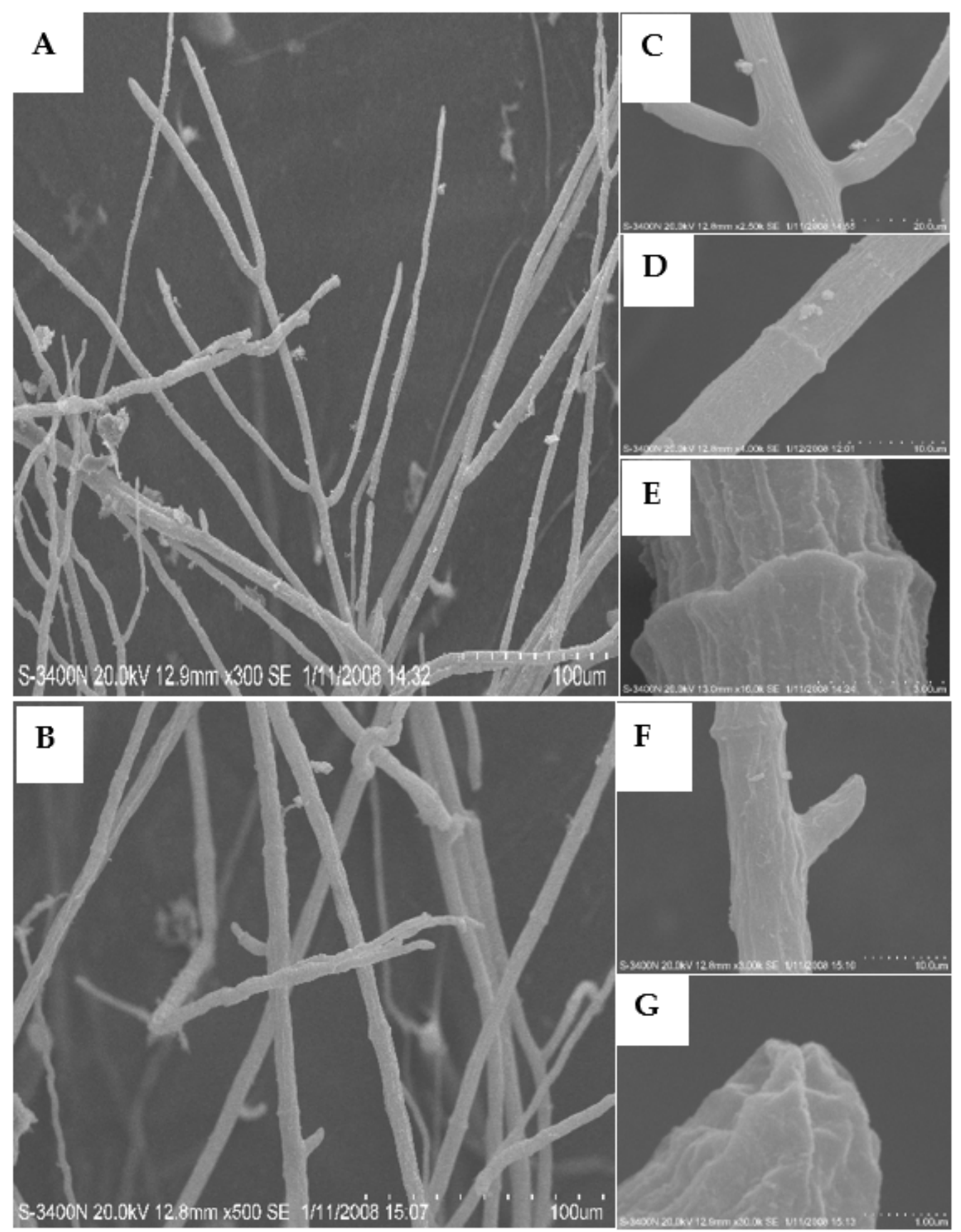

Figure 2. Scanning electron micrographs (SEM) of the hyphae from the colony of $B$. cinerea grown on PDA medium in the absence of L13 (control). Scale bars: (A,B) $100.0 \mu \mathrm{m}$; (C) $20.0 \mu \mathrm{m}$; (D,F) $10.0 \mu \mathrm{m}$; (E) $3.0 \mu \mathrm{m} ;(\mathrm{G}) 1.0 \mu \mathrm{m}$. 
SEM images of the mycelia grown on the PDA with 50 and $100 \mu \mathrm{g} / \mathrm{mL}$ of L13 are shown in Figures 3 and 4 . After treatment with $50 \mu \mathrm{g} / \mathrm{mL}$ of L13, the growth of hyphae and its septa was similar to the blank controls (Figure 3A,B,F), but mycelial density increased significantly (Figure 3A,B). Meanwhile, the number of branches and septa of hyphae increased significantly (Figure 3A-C,E). The smoothy surface of the hypha surface was covered with many small shallow holes (Figure 3D,G). The structure of the tip of the hypha was deformed (Figure 3E,F). When treated with $100 \mu \mathrm{g} / \mathrm{mL}$ of L13, the morphological traits of mycelia showed a strong inhibitory effect (Figure 4). Mycelial density increased significantly, and some hyphae were ruptured (Figure $4 \mathrm{~A}-\mathrm{C}, \mathrm{F}$ ). The tendency to increase the number of branches and septa of hyphae was more obvious (Figure 4B,C). Moreover, there were irregular ramifications or abnormal configurations (contracted or swelling up) on the tip of the hypha (Figure 4D,E,G).

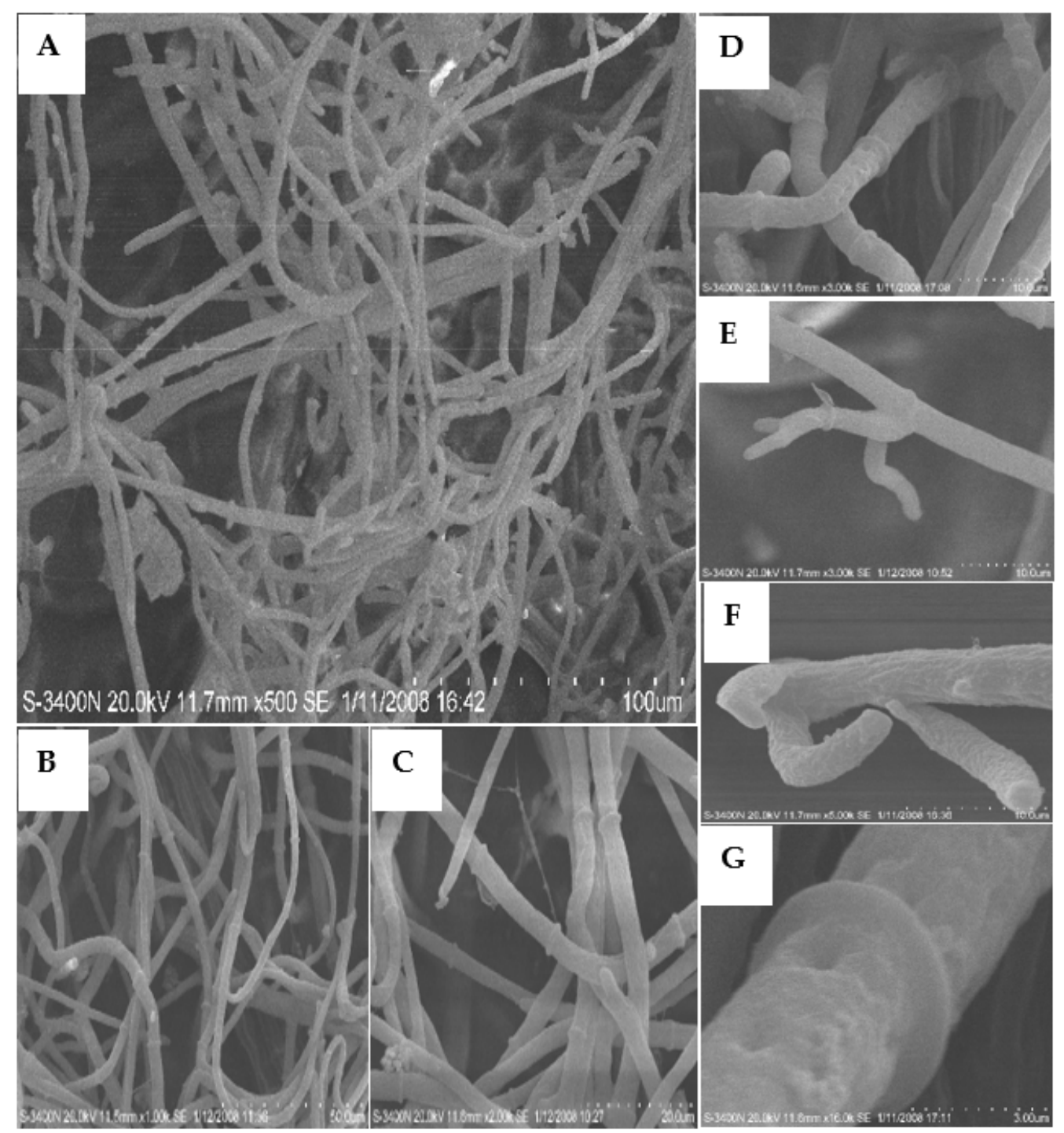

Figure 3. SEM images of the hyphae from the colony of B. cinerea grown on PDA medium with $50 \mu \mathrm{g} / \mathrm{mL}$ of L13. Scale bars: (A) $100.0 \mu \mathrm{m}$; (B) $50.0 \mu \mathrm{m}$; (C) $20.0 \mu \mathrm{m}$; (D-F) $10.0 \mu \mathrm{m}$; (G) $3.0 \mu \mathrm{m}$. 


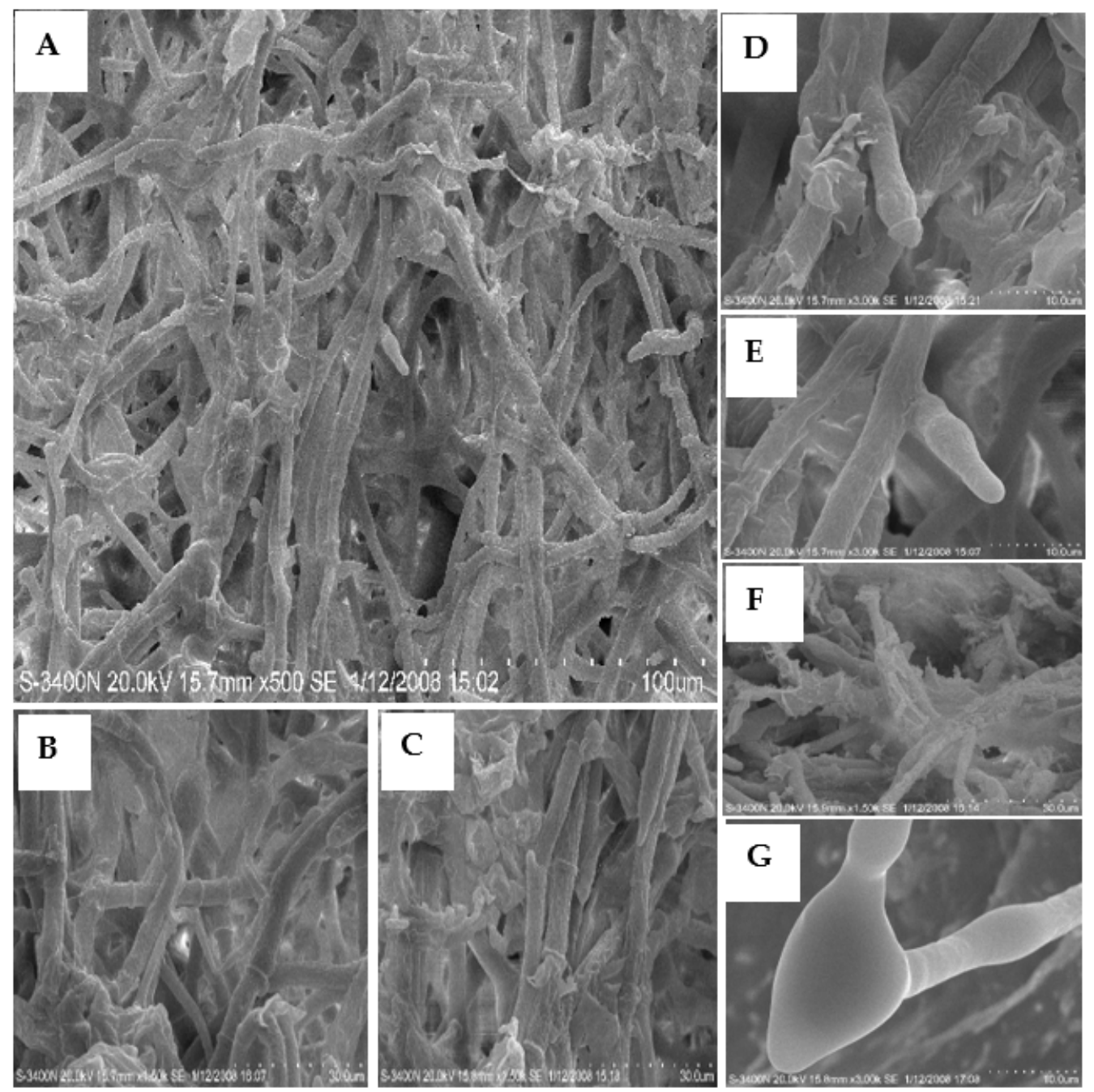

Figure 4. SEM images of the hyphae from the colony of $B$. cinerea grown on PDA medium with $100 \mu \mathrm{g} / \mathrm{mL}$ of L13. The mycelium swelled, parts of mycelia ruptured and formed abnormal configurations on the mycelium tip. Scale bars: (A) $100.0 \mu \mathrm{m}$; (B,C,F) $30.0 \mu \mathrm{m} ;(\mathbf{D}, \mathbf{E}, \mathbf{G}) 10.0 \mu \mathrm{m}$.

B. cinerea mycelial tips $(5 \mathrm{~mm}$ ) from the margins of the actively growing colony on the PDA medium were also examined by TEM (Figures 5-7). The mycelia of $B$. cinerea grown in the absence of L13 showed many of the cytological and ultrastructural features typical of vegetative hyphae of the genus [28] (Figure 5). The cell walls and septa of the hyphae were uniform. There were abundant organelles in the cytoplasm, such as the cell wall, vacuole, mitochondrial, endoplasmic reticulum, electron density, and lipid body.

In the presence of $\mathbf{L 1 3}$ at $50 \mu \mathrm{g} / \mathrm{mL}$, different ultrastructural modifications occurred in the hyphae (Figure 6). The amount of vacuole in the cell (Figure 6A,C,D) and electron density in the cytoplasm (Figure 6A,B,F) increased. The cell wall exhibited a decomposition trend (Figure 6E), and the tip of the hypha presented abnormal growth (Figure 6F,G). At a higher concentration $(100 \mu \mathrm{g} / \mathrm{mL}), \mathbf{L 1 3}$ caused more conspicuous cytological changes (Figure 7). The striking characteristic was the cell wall decomposition (Figure 7A,C,D). The most extraordinary change in the intracellular is the organism disorder and the disappearance of most membrane-like structures, such as vacuole (Figure 7E,F). 


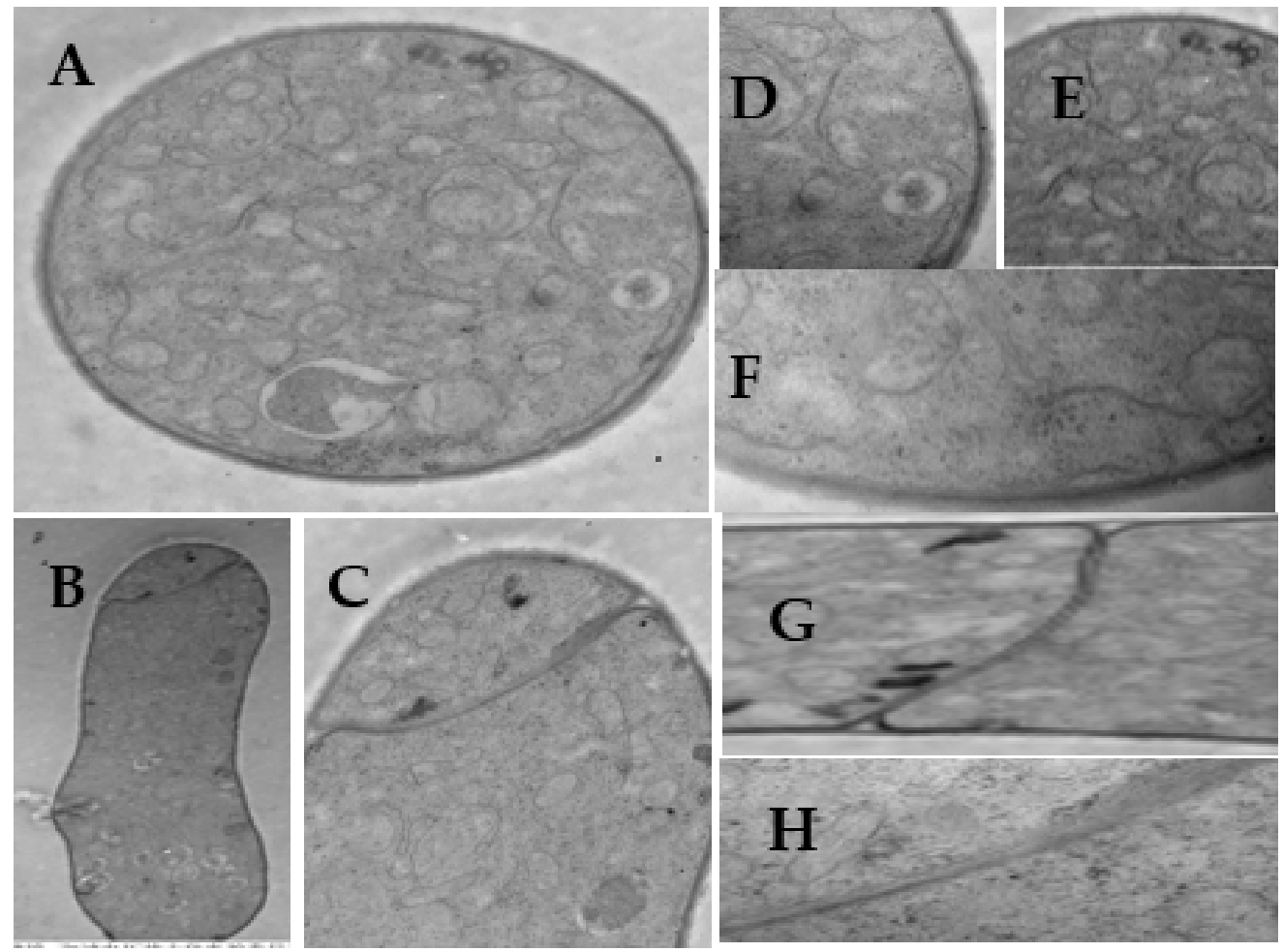

Figure 5. Transmission electron micrographs (TEM) of $B$. cinerea hyphae in the untreated control. Scale bars: (A,B,G,H) $1.0 \mu \mathrm{m}$; (C-E) $0.5 \mu \mathrm{m}$; (F) $0.1 \mu \mathrm{m}$.

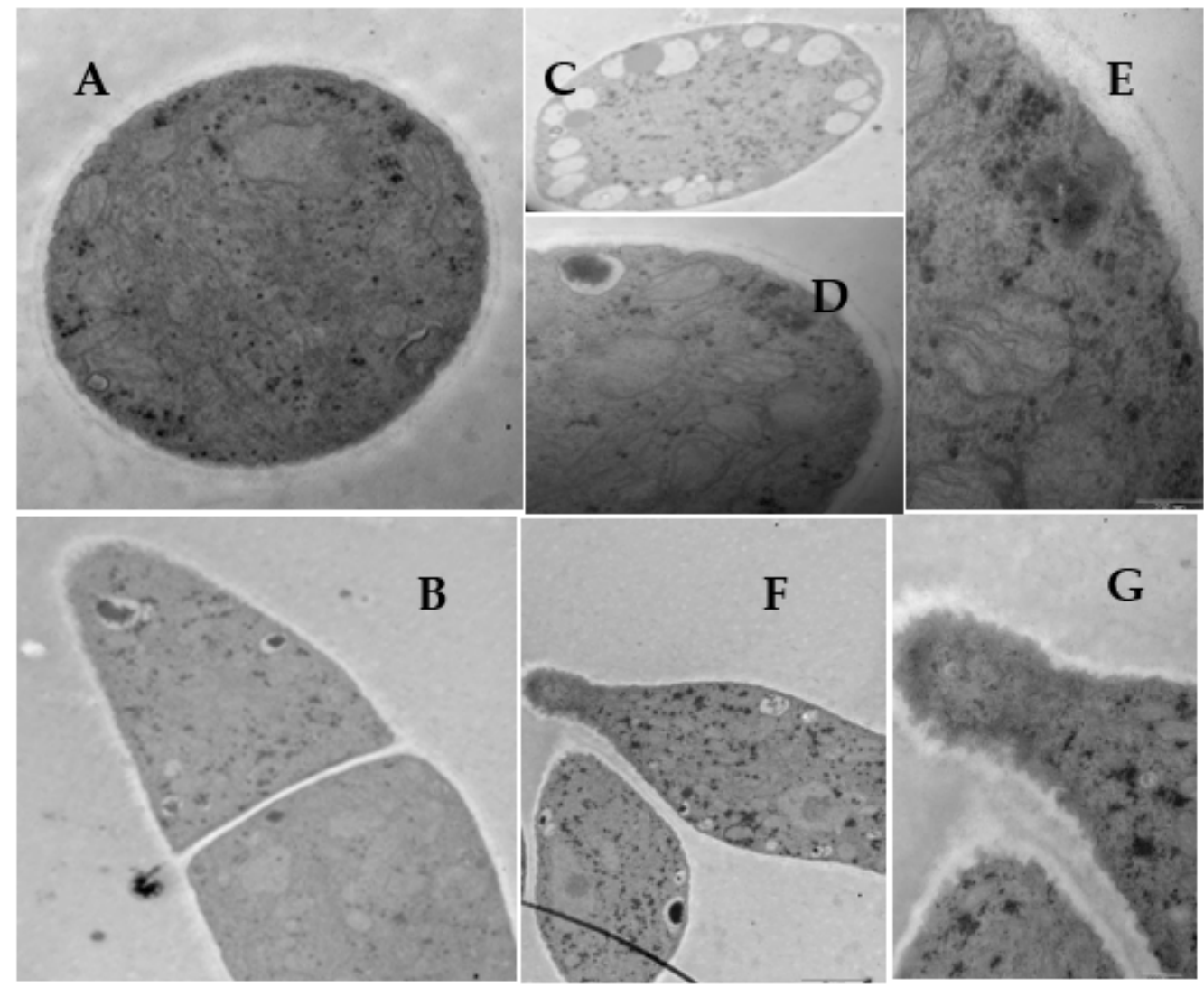

Figure 6. TEM images of $B$. cinerea hyphae with $50 \mu \mathrm{g} / \mathrm{mL}$ of L13. Scale bars: $(\mathbf{A}, \mathbf{B}, \mathbf{G}, \mathbf{H}) 1.0 \mu \mathrm{m}$; (C-E) $0.5 \mu \mathrm{m}$; (F) $0.1 \mu \mathrm{m}$. 


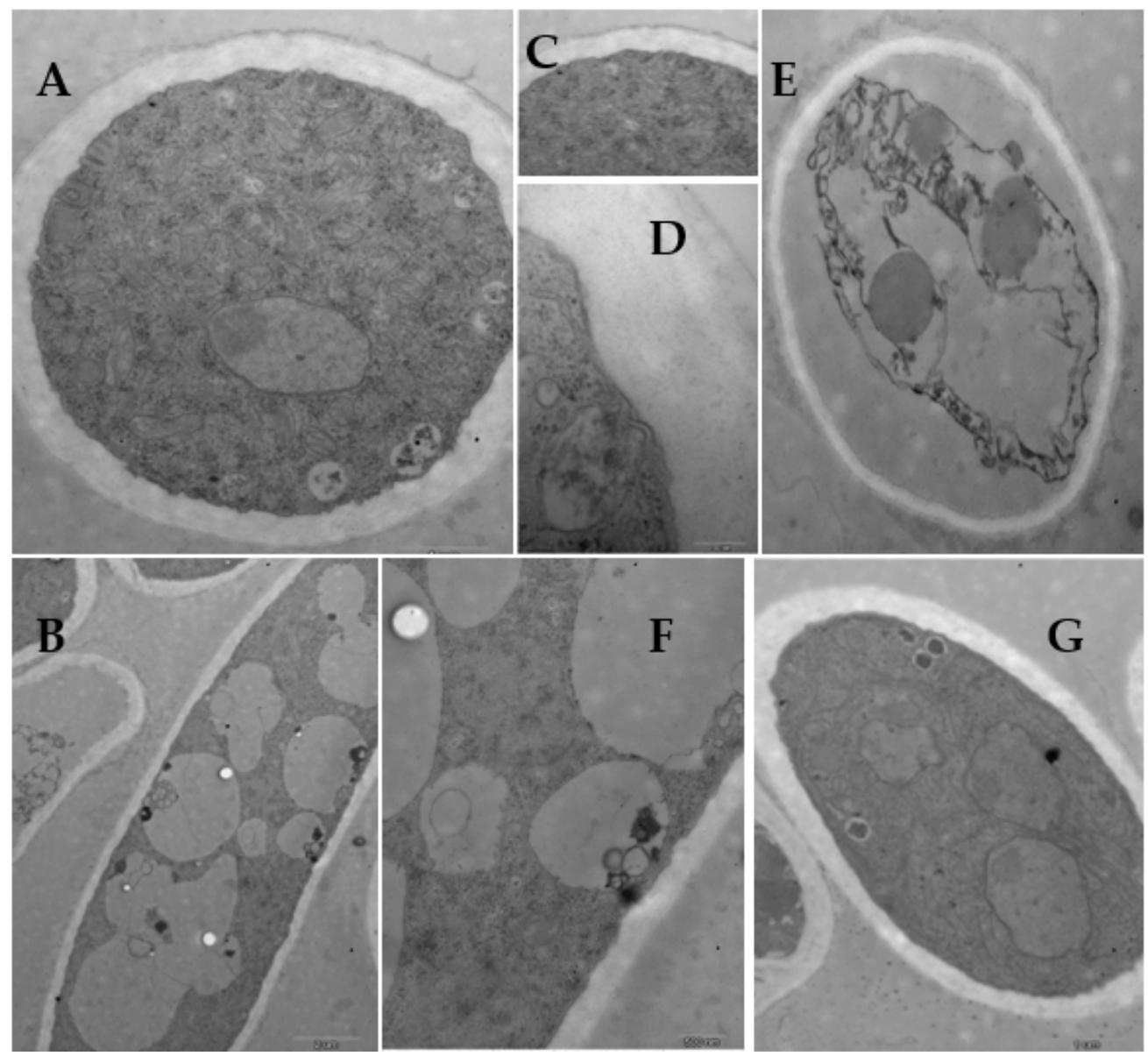

Figure 7. TEM images of B. cinerea hyphae with $100 \mu \mathrm{g} / \mathrm{mL}$ of L13. Scale bars: $(\mathbf{A}, \mathbf{B}, \mathbf{G}) 1.0 \mu \mathrm{m}$; (C-E) $0.5 \mu \mathrm{m}$; (F) $0.1 \mu \mathrm{m}$.

SEM and TEM observations revealed that growth inhibition of B. cinerea as a response to L13 was accompanied by obvious morphological and cytological changes, including excessive branching, irregular ramification or abnormal configuration (contracted or swelling up), and the decomposition of cell wall and vacuole. The cell wall of fungi is a sturdy structure providing physical protection and osmotic support, consisting of a complex of macromolecules with chitin, glucan, and mannose interconnected by covalent bonds. Hyphae growth, branching, cell fusion, and other morphogenetic events all depend on a balance between decomposition and extension of the hyphae wall and synthesis and the incorporation of new wall material $[29,30]$. In the present study, the hyphae walls of B. cinerea were decomposed, and excessive branching of the hyphae was observed, which is completely different from ergosterol biosynthesis inhibitor fungicides that inhibit the cell wall [30-32]. Another noteworthy alteration, however, was the disruption of the endomembrane system, especially vacuoles and secretory vesicles. The vacuole plays an important role in maintaining the fungal turgor pressure, and it is greatly important for mycelial growth. In this study, the vacuoles and vesicles related to cell wall synthesis [33] observed in control cells of B. cinerea were distorted and disrupted in L13 treated cells. Hence, it may confirm that $\mathbf{L 1 3}$ disrupts the endomembrane system indirectly by binding to the cell surface or directly from inside the cell.

\subsubsection{Effect of L13 on Mycelial Electrolyte Leakage of B. cinerea}

To examine the effect of $\mathbf{L 1 3}$ on the cell membrane, the electrical conductivity of mycelia suspension was measured using commercial fungicides procymidone as a positive control (Figure 8). The conductivity of mycelia suspension treated with L13 and procymidone greatly increased compared with the conductivity of the control mycelia 
at all treatment times. $\mathbf{L 1 3}$ induced more significant electrolyte leakage from hyphae than procymidone. Thus, it was proposed that L13 was related to the impairment of the cell membrane.

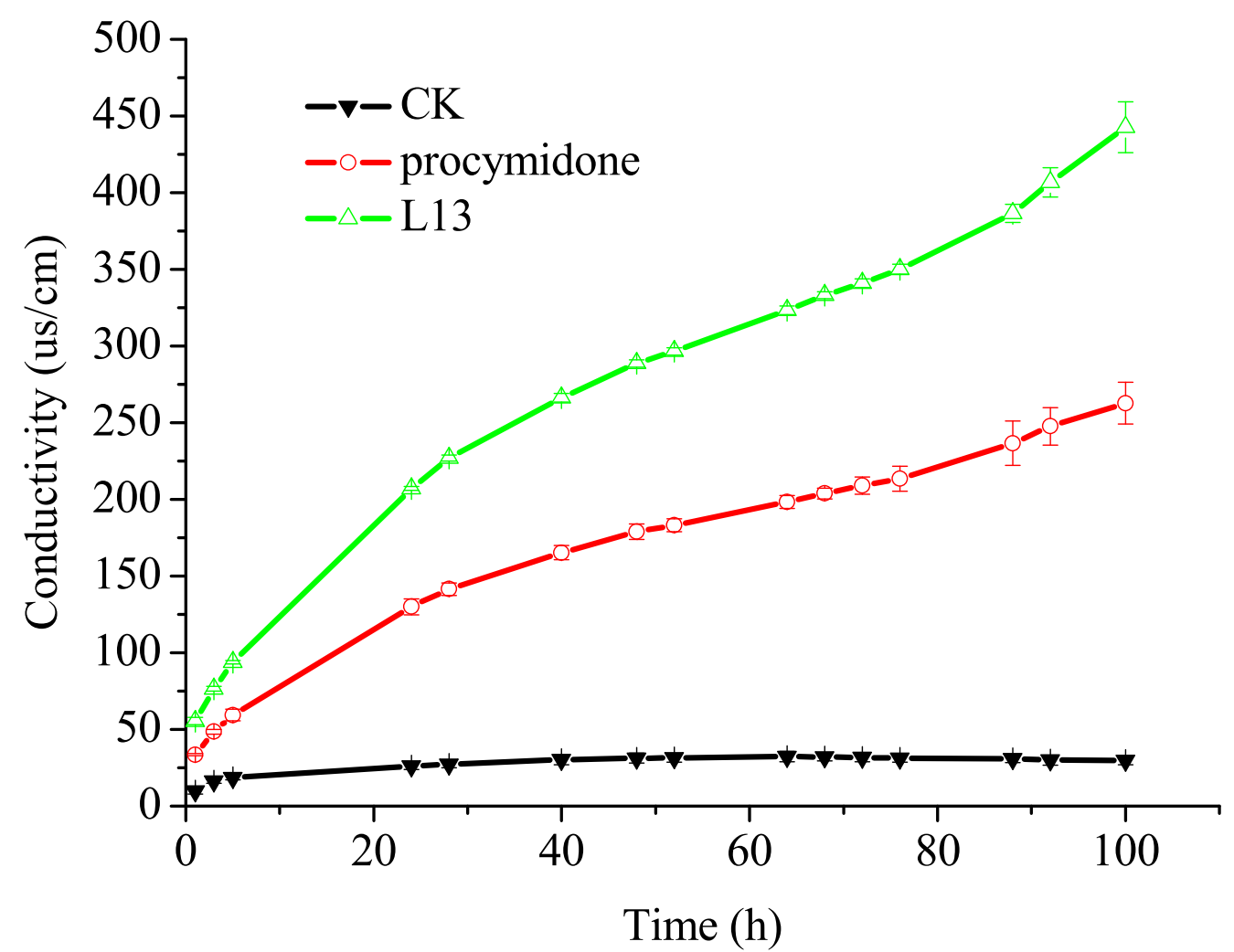

Figure 8. Electrolyte leakage from B. cinerea suspensions during different time exposure to different fungicides.

Electrolyte leakage is always used to indicate cell membrane permeability of hyphae exposed to various fungicides. The alteration of conductivity induced by L13 was significantly greater than the alteration caused by procymidone which has been considered to cause some defects in the membrane but had no effect on the ion leakage or the water permeability [34]. The result indicated that L13 caused certain damage to the mycelia cell membrane system, induced electrolyte leakage from the cell, and increased the conductivity of the solution. Thus, the decomposition of cell walls was most likely to be associated with biochemical changes in the plasmalemma induced by L13. We have reported that L13 could reduce the content of the DNA and polysaccharide in the intact mycelia of $B$. cinerea [35], which provided a possible confirmation for the leakage of cellular content.

\subsubsection{Effect of L13 on Mycelial Respiration of $B$. cinerea}

The effects of $\mathbf{L 1 3}$ and famoxadone on the oxygen consumption of intact mycelia are shown in Table 2. L13 almost did not affect the oxygen consumption of intact mycelia with $2.15 \%$ inhibition at $50 \mu \mathrm{g} / \mathrm{mL}$ and $17.44 \%$ inhibition at $100 \mu \mathrm{g} / \mathrm{mL}$ of L13, while famoxadone, a respiration inhibitor, exhibited a strong effect on the oxygen consumption of intact mycelia with $33.16 \%$ inhibition at $50 \mu \mathrm{g} / \mathrm{mL}$ and $60.42 \%$ inhibition at $100 \mu \mathrm{g} / \mathrm{mL}$ of famoxadone. These results proved that L13 was not a respiration inhibitor and could not disturb the energy generation system of $B$. cinerea. 
Table 2. Respiratory inhibition of intact mycelia of B. cinerea by L13.

\begin{tabular}{|c|c|c|c|}
\hline Inhibitors $(\mu \mathrm{g} / \mathrm{mL})$ & $\mathrm{R}_{0}(\mathrm{nmol} \mathrm{O} / \mathrm{g} / \mathrm{min})$ & $\left.R_{1}(\mathrm{nmol} \mathrm{O})_{2} / \mathrm{g} / \mathrm{min}\right)$ & $\operatorname{IR}(\%) *$ \\
\hline L13 (50) & 173.51 & 169.93 & $2.15 \mathrm{~d}$ \\
\hline L13 (100) & 173.51 & 143.48 & $17.44 \mathrm{c}$ \\
\hline Famoxadone (50) & 173.51 & 115.99 & $33.16 \mathrm{~b}$ \\
\hline Famoxadone (100) & 173.51 & 68.79 & $60.42 \mathrm{a}$ \\
\hline $\mathrm{CK}$ & 173.51 & - & - \\
\hline
\end{tabular}

\subsection{Control Effect of L13 against Tomato Gray Mold in Field Efficacy Trials}

Gray mold caused by B. cinerea is a devastating disease on tomatoes, leading to severe economic losses in many countries worldwide [25]. The prevailing method to control gray mold is chemical fungicides applications [36]. Considering the commercial development of L13, field efficacy trials must be carried out under complex environmental scenarios, including the influences of sunlight, natural temperature and humidity, and environmental microorganisms. This is a process that must go through the commercialization of a pesticide. The good in vitro and pot test activity of L13 against $B$. cinerea must be verified by field trials on tomatoes.

In two locations over 2 years, the control effect of L13 against B. cinerea on tomatoes could reach $72-76 \%$ at a rate of $225 \mathrm{~g}$ ai ha ${ }^{-1}$ in Yuncheng city, which was better than the commercial fungicide iprodione $50 \% \mathrm{WP}$ at the same dosage (Table 3). When the dosage of L13 was $450 \mathrm{~g}_{\text {ai ha }}{ }^{-1}$, the field control effect could be up to $83 \%$. In Gaocheng city, L13 still demonstrated better control efficiency than iprodione 50\% WP at the same dosage of $225 \mathrm{~g}$ ai ha ${ }^{-1}$, which was comparable to that in Yucheng city. The present field trials indicate that L13 has great potential for commercial development.

Table 3. Control effect of L13 against B. cinerea on tomatoes in field efficacy trials.

\begin{tabular}{|c|c|c|c|c|c|c|}
\hline \multirow[b]{2}{*}{ Treatment } & \multicolumn{2}{|c|}{ Dosage } & \multicolumn{2}{|c|}{ First Year } & \multicolumn{2}{|c|}{ Second Year } \\
\hline & $\begin{array}{c}\text { Dilution } \\
\text { Concentration }\end{array}$ & g.ai ha ${ }^{-1}$ & Disease Index & Control Effect $(\%)$ * & Disease Index & Control Effect (\%) * \\
\hline \multicolumn{7}{|c|}{ Site: Yuncheng, Shanxi Province, China } \\
\hline L13 50\% WP & 1000 & 450 & $2.87^{\circ}$ & $82.85 \mathrm{a}$ & 2.78 & $83.32 \mathrm{a}$ \\
\hline L13 50\% WP & 2000 & 225 & 4.72 & $71.79 \mathrm{~b}$ & 3.92 & $76.48 \mathrm{~b}$ \\
\hline $\begin{array}{c}\text { Iprodione } 50 \% \\
\text { WP }\end{array}$ & 2000 & 225 & 5.54 & $66.89 \mathrm{c}$ & 5.19 & $68.87 \mathrm{c}$ \\
\hline $\begin{array}{l}\text { Untreated } \\
\text { control }\end{array}$ & - & - & 16.73 & - & 16.67 & - \\
\hline \multicolumn{7}{|c|}{ Site: Gaocheng, Hebei Province, China } \\
\hline L13 50\% WP & 1000 & 450 & $2.40^{\circ}$ & $71.66 \mathrm{ab}$ & 1.65 & 80.38 a \\
\hline L13 50\% WP & 2000 & 225 & 2.83 & $66.59 \mathrm{~b}$ & 1.71 & $79.67 \mathrm{a}$ \\
\hline $\begin{array}{l}\text { Iprodione } 25 \% \\
\text { SC }\end{array}$ & 400 & 562.5 & 1.98 & $76.62 \mathrm{ab}$ & 2.15 & $71.22 \mathrm{a}$ \\
\hline $\begin{array}{l}\text { Untreated } \\
\text { control }\end{array}$ & - & - & 8.47 & - & 8.41 & - \\
\hline
\end{tabular}

* Different letters (a, b, c) are significantly different according to Duncan's multiple range test $(p=0.05)$.

\subsection{Toxicological Test of L13}

As shown in Table 4, the toxicological tests indicated that L13 was a low toxicological compound [LD $\mathrm{LD}_{50} 1470 \mathrm{mg} / \mathrm{kg} \cdot \mathrm{BW}$ (male) and $2150 \mathrm{mg} / \mathrm{kg} \cdot \mathrm{BW}$ (female) for acute oral and $\mathrm{LD}_{50}>2000 \mathrm{mg} / \mathrm{kg} \cdot \mathrm{BW}$ (male and female) for acute dermal] based on classification standard procedure of the People's Republic of China. The teratogenesis, mutagenesis, and carcinogenesis tests were negative. Therefore, it can be concluded that L13 is safe for rats and rabbits, which shows great potential for further commercial development. 
Table 4. Toxicological profile of L13.

\begin{tabular}{cc}
\hline Test Item & Value \\
\hline Acute oral (rats) & $\mathrm{LD}_{50} 1470 \mathrm{mg} / \mathrm{kg} \cdot \mathrm{BW}($ male); LD $502150 \mathrm{mg} / \mathrm{kg} \cdot \mathrm{BW}(\mathrm{female})$ \\
Acute dermal (rats) & $\mathrm{LD}_{50}>2000 \mathrm{mg} / \mathrm{kg} \cdot \mathrm{BW}\left(\right.$ male); $\mathrm{LD}_{50}>2000 \mathrm{mg} / \mathrm{kg} \cdot \mathrm{BW}(\mathrm{female})$ \\
Eye irritation (rabbits) & No irritation \\
Skin irritation (rabbits) & No irritation \\
Teratogenesis & Negative \\
Mutagenesis & Negative \\
Carcinogenesis & Negative \\
\hline
\end{tabular}

\section{Materials and Methods}

\subsection{Materials and Reagents}

(N-(2-trifluoromethyl-4-chlorphenyl)-2-oxocyclohexyl sulfonamide) (L13) was prepared according to our previously reported method [18], and formulated as either a 50\% $(\mathrm{w} / \mathrm{w})$ or $25 \%(\mathrm{w} / \mathrm{w})$ WP (wettable powder) from L13 (50\% or $25 \%$ ), naphthalenesulfonate $(2 \%)$, lignosulfonate $(5 \%)$, and white carbon black $(43 \%$ or $68 \%)$, respectively. Carbendazim 50\% WP was purchased from Jiangsu Xinyi Pesticide Factory (Xuzhou, China). Diethofencarb 50\% WP was provided by the Institute of Vegetables and Flowers, Chinese Academy of Agricultural Sciences (Beijing, China). Iprodione 50\% WP was obtained from Bayer Crop Science (China) Co., Ltd. (Hangzhou, China). Iprodione $25 \%$ SC was acquired from Jiangsu Kuaida Agrochemical Co., Ltd. (Nantong, China). All other chemicals were used as received without further purification.

The $B$. cinerea strains, which had resistance to carbendazim (HM-1), diethofencarb (HM-2), and iprodione (HM-3) for greenhouse pot studies, were provided by the Institute of Vegetables and Flowers, Chinese Academy of Agricultural Sciences (Beijing, China).

\subsection{Greenhouse Test of L13 against B. cinerea on Tomato Resistant to Commercial Fungicides}

The experiments were conducted in the greenhouse of the Institute of Vegetables and Flowers, Chinese Academy of Agricultural Sciences. The maximum and minimum temperatures of the greenhouse were $29^{\circ} \mathrm{C}$ and $19{ }^{\circ} \mathrm{C}$, respectively, and the average temperature was $24^{\circ} \mathrm{C}$. B. cinerea strains showing resistance to carbendazim, diethofencarb, and iprodione were cultivated on potato dextrose agar (PDA) plates for $4-5 \mathrm{~d}$ at room temperature. Tomato seeds (Ziyu) were sown in ceramic pots (300 $\mathrm{mm}$ in diameter) containing $0.6 \mathrm{~kg}$ of soil sterilized with formaldehyde (4-5 seeds for each pot). When plants were grown to the five-leaf stage, an aqueous solution of 25\% L13 WP (at dilution multiples of 1000 and 2000 times) was sprayed preventatively on the plant surface. Commercial fungicides of carbendazim 50\% WP at dilution multiple of 500 times, diethofencarb 50\% WP at dilution multiple of 1400 times, and iprodione 50\% WP at dilution multiple of 1000 times were sprayed similarly on plant surface as positive controls, and equal amounts of water were sprayed as the blank control. The normalized water consumption per hectare was $750 \mathrm{~L} \mathrm{ha}^{-1}$ for each treatment. After the application, the plants were inoculated with the $B$. cinerea strains. There were three replicates for each concentration. The severity of the disease was assessed according to a nine-grade classification at $7 \mathrm{~d}$ after inoculation [37], by which time the disease in the untreated control had fully developed.

\subsection{Effect of L13 on Mycelial Ultrastructure of B. cinerea}

$B$. cinerea mycelial tips $(5 \mathrm{~mm})$ from the margins of the actively growing colony on the PDA medium amended with 0,50 , and $100 \mu \mathrm{g} / \mathrm{mL}$ of $\mathbf{L 1 3}$ were cut down after being cultured for 3 days. Then the mycelial tips were treated with $4 \%$ glutaraldehyde at $4{ }^{\circ} \mathrm{C}$, then rinsed with $0.1 \mathrm{M}$ phosphate buffer ( $\mathrm{pH} 7.3$ ) and fixed with $1 \%$ w/v osmium tetraoxide solution. After being rinsed with $0.1 \mathrm{M}$ phosphate buffer three times, the mycelium block was dehydrated using a series of acetone solutions in the order of concentration: 30\%, $50 \%, 70 \%, 80 \%, 90 \%$, and anhydrous acetone. The processes of drying at a critical point, mounting, and gold spraying were completed at last and examined in a scanning electron 
microscope (S-3400N, Hitachi, Nissei Sanyo, Tokyo, apan) with an accelerating voltage of $18-20 \mathrm{kV}$.

The mycelial blocks were prepared according to the method given in Section 2.3. After dehydrating and embedding in Epon 112, thin sections were cut and double-stained with uranyl acetate and lead citrate. The grids were examined with a JEOL-1230 (JEOL, Tokyo, Japan) transmission electron microscope.

\subsection{Effect of L13 on Mycelial Electrolyte Leakage of B. cinerea}

Mycelial discs (5 $\mathrm{mm}$ in diameter) of $B$. cinerea grown on PDA plates were cut from the colony's margins and placed in PDA liquid medium with $200 \mathrm{r} / \mathrm{min}$ shaking for 3 days. The mycelia in the culture medium were collected and washed three times by sterile distilled water and subsequently, filtered and weighed. A stock solution of L13 and commercial fungicide procymidone as a positive control were diluted with sterile distilled water to $50 \mu \mathrm{g} / \mathrm{mL}$, respectively. After adding $1.0 \mathrm{~g}$ of fresh mycelia into different solutions mentioned above, the conductivities of the solutions were measured using the DDS-11C model conductivity detector at $0,1,3,5,24,28,40,48,52,64,68$, $72,76,88,92$, and $100 \mathrm{~h}$ after treatment. The experiment was repeated twice with three replicates per treatment.

\subsection{Effect of L13 on Mycelial Respiration of B. cinerea}

Mycelial plugs of $B$. cinerea from 3 days old colony margins were transferred to conical flasks containing $150 \mathrm{~mL}$ of PDA liquid medium for shake culture $\left(25^{\circ} \mathrm{C}, 150 \mathrm{r} / \mathrm{min}\right)$. After 5 days, mycelia were washed three times with $50 \mathrm{mM}$ potassium phosphate buffer $(\mathrm{pH}$ 7.2) and resuspended in $0.1 \mathrm{M}$ phosphate buffer ( $\mathrm{pH} 7.2)$, containing $2 \%$ glucose to afford mycelial suspension at a concentration of $50 \mathrm{mg}$ fresh weight of mycelia per milliliter. The mycelial suspension was treated with 50 and $100 \mu \mathrm{g} / \mathrm{mL}$ of $\mathbf{L 1 3}$ and famoxadone, respectively. All measurements were carried out at $25 \pm 1{ }^{\circ} \mathrm{C}$. The ratio of the mycelial oxygen consumption was tested by oxygraphy (DW1, Hansatech Instruments Ltd., England), and the inhibition of respiration was calculated using the following formula:

$$
\mathrm{I}_{\mathrm{R}}=\left(\mathrm{R}_{0}-\mathrm{R}_{1}\right) / \mathrm{R}_{0} \times 100
$$

$I_{R}$ : inhibition of respiration (\%); $R_{0}, R_{1}$ : the ratio of mycelial oxygen uptake pre and post addition of fungicides ( $\mathrm{nmol} \mathrm{O}_{2} / \mathrm{min} / \mathrm{mg}$ mycelia).

\subsection{Field Efficacy Trials of L13 against B. cinerea on Tomatoes}

The field efficacy trials of L13 against tomato gray mold were conducted in two locations of Yuncheng, Shanxi Province, and Gaocheng, Hebei Province. The experiments were conducted according to the National Agriculture Industry Standard of "Pesticideguidelines for the field efficacy trials (I)-Fungicides against gray mold of vegetables" [38]. Tomato Jinpeng No. 1 was used as the experimental cultivar. There were six treatments in each trial, and the area of each plot was $5 \times 3 \mathrm{~m}$ with four replications (24 plots).

When tomato plants were grown to the five-leaf stage, an aqueous solution of L13 $50 \% \mathrm{WP}$ at a rate of 450 and $225 \mathrm{~g}$ ai ha ${ }^{-1}$ was sprayed onto the plants using a hydraulic knapsack electric sprayer (CD-16B, Chaoda Instrument Co., Ltd., Taizhou, China) with a single cone nozzle operating at a typical working pressure $0.3 \mathrm{MPa}$. Iprodione $50 \% \mathrm{WP}$, or iprodione $25 \%$ SC at a rate of 225 and $562.5 \mathrm{~g}_{\text {ai ha }}{ }^{-1}$ were used as positive controls. Three applications were conducted at an interval of $7 \mathrm{~d}$. The disease was assessed according to a nine-grade classification $7 \mathrm{~d}$ after the last application $[37,38]$.

\subsection{Toxicological Test of $L 13$}

The acute oral and dermal toxicity test on Wistar rats, eye and skin irritation test on rabbits, and Ames mutagenicity test were commissioned by the Institute for the Control of Chemical Toxicity in Tianjin. The bone marrow cell micronucleus assay and testis chromosomal aberration test of mice were commissioned by Tianjin Center for Disease 
Control and Prevention. All the toxicological tests were carried out according to the Toxicological Test Methods for Pesticide Registration (GB 15670-1995).

Based on the preliminary experiment, Horn's method was used to determine the acute oral toxicity of L13. The dosage applied for rats was $464,1000,2150$, and $4640 \mathrm{mg} / \mathrm{kg}$. BW. For the acute dermal toxicity test, the dosage applied for rats was $2000 \mathrm{mg} / \mathrm{kg} \cdot \mathrm{BW}$. For the eye and skin irritation test, rabbits with bodyweight from 2.5 to $3.0 \mathrm{~kg}$ were used, and 0.1 and $0.5 \mathrm{~kg}$ of L13 was applied to the eyes and skin, respectively. For the Ames mutagenicity test, $0.05-1.0 \mathrm{mg}$ per dish of L13 was applied, and fenaminosulf ( $50 \mu \mathrm{g} / \mathrm{dish}$ ), 2-aminofluorene (20 $\mu \mathrm{g} /$ dish), and 1,8-dihydroxyanthraquinone (50 $\mu \mathrm{g} /$ dish) were used as the positive controls. For the mouse bone marrow cell micronucleus assay, the dosages applied were $165,82.5,41.3$, and $8.3 \mathrm{mg} / \mathrm{kg} \cdot \mathrm{BW}$, and cyclophosphamide $(60 \mathrm{mg} / \mathrm{kg} \cdot \mathrm{BW})$ was used as a positive control. For the testis chromosomal aberration test of mice, the dosages applied were 206.2, 103.1, and $51.6 \mathrm{mg} / \mathrm{kg} \cdot \mathrm{BW}$, and mitomycin C (2 mg/kg.BW) was used as a positive control.

\subsection{Statistical Analysis}

Statistical analysis was performed using the Origin software (OriginLab 2018, Northampton, MA, USA). One-way ANOVA was performed, followed by Duncan's multiple range test. $p$-values $<0.05$ were accepted as significant.

\section{Conclusions}

In this study, the antifungal activity of $\mathbf{L} 13$ against $B$. cinerea resistant to commercial fungicides has been studied, and $\mathbf{L 1 3}$ provided good control against $B$. cinerea resistant to commercial fungicides such as carbendazim, diethofencarb, and iprodione in the pot culture experiments. To elucidate the biochemical mode of action of $\mathbf{L} 13$ against $B$. cinerea, the effects of L13 on the ultrastructural of hyphae, electrolyte leakage, and respiration of mycelia suspension were explored. After treatment with L13, SEM observations showed that the mycelial density of $B$. cinerea was increased significantly, and some hyphae were ruptured. Moreover, there were irregular ramifications or abnormal configurations (contracted or swelling up) on the tip of the hypha. SEM observations demonstrated that at a higher concentration, L13 caused more conspicuous cytological changes, especially concerning the decomposition of the cell wall, which may confirm that L13 disrupted the endomembrane system indirectly by binding to the cell surface or directly from inside the cell. The alteration of conductivity induced by L13 was greater than the alteration caused by procymidone as a positive control, implying that L13 caused certain damage to the mycelia cell membrane system. Oxygen consumption of intact mycelia experiments proved that L13 was not a respiration inhibitor. In two locations over 2 years, the field control effect of L13 against tomato gray mold was better than the commercial fungicide iprodione at the same dosage. The toxicological tests indicated that L13 is safe for rats and rabbits. The present studies preliminarily confirmed that L13 has great potential for commercial development. Further research on the mode of action at the molecular level and field efficacy trials against more plant pathogens will be performed. As a common strategy to address the challenge of resistance, the sulfonamide $\mathbf{L 1 3}$ can be combined with other fungicides with a different mode of action, such as dimethomorph, fluopicolide, famoxadone, and pyraclostrobin.

Author Contributions: Data curation, methodology, investigation, writing—original draft, X.Y.; data curation, methodology, investigation, S.C. and W.S.; formal analysis, resources, validation, X.Z.; Software, visualization, D.Y.; conceptualization, supervision, funding acquisition, writing-review and editing, project administration, H.Y. and D.W. All authors have read and agreed to the published version of the manuscript.

Funding: This research was funded by the National Key Research Development Program of China (2019YFD1002000).

Institutional Review Board Statement: Not applicable.

Informed Consent Statement: Not applicable. 
Data Availability Statement: The data presented in this study are available in this article.

Acknowledgments: Special thanks to Baoju Li at the Institute of Vegetables and Flowers, Chinese Academy of Agricultural Sciences, who helped in the Greenhouse test of L13 against B. cinerea regarding tomato resistance to commercial fungicides.

Conflicts of Interest: The authors declare no conflict of interest.

\section{References}

1. Caseys, C.; Shi, G.; Soltis, N.E.; Gwinner, R.; Corwin, J.A.; Atwell, S.; Kliebenstein, D.J. Quantitative interactions drive Botrytis cinerea disease outcome across the plant kingdom. BioRxiv 2018, 507491.

2. Mercier, A.; Carpentier, F.; Duplaix, C.; Auger, A.; Pradier, J.; Viaud, M.; Gladieux, P.; Walker, A.-S. The polyphagous plant pathogenic fungus Botrytis cinerea encompasses host-specialized and generalist populations. Environ. Microbiol. 2019, 21, 4808-4821. [CrossRef] [PubMed]

3. Dean, R.; Van Kan, J.A.; Pretorius, Z.A.; Hammond-Kosack, K.E.; Di Pietro, A.; Spanu, P.D.; Foster, G.D. The Top 10 fungal pathogens in molecular plant pathology. Mol. Plant Pathol. 2012, 13, 414-430. [CrossRef]

4. Poveda, J.; Barquero, M.; González-Andrés, F. Insight into the microbiological control strategies against Botrytis cinerea using systemic plant resistance activation. Agronomy 2020, 10, 1822. [CrossRef]

5. Shao, W.; Zhao, Y.; Ma, Z. Advances in understanding fungicides resistance in Botrytis cinerea in China. Phytopathology 2021, 111, 455-463. [CrossRef]

6. Bardas, G.A.; Veloukas, T.; Koutita, O.; Karaoglanidis, G.S. Multiple resistance of Botrytis cinerea from kiwifruit to SDHIs, QoIs and fungicides of other chemical groups. Pest Manag. Sci. 2010, 66, 967-973. [CrossRef]

7. Cai, N.; He, L.; Wang, K.; Feng, Z.; Cui, Z.; Ji, M.; Qi, Z.; Qin, P.; Li, X. Novel sulfonamides against Botrytis cinerea with no positive cross-resistance to commercial fungicides: Design, synthesis and SAR study. Bioorg. Med. Chem. Lett. 2020, 30, 126859. [CrossRef]

8. Fenga, M.; Tanga, B.; Liang, H.S.; Jiang, X. Sulfur containing scaffolds in drugs: Synthesis and application in medicinal chemistry. Curr. Top. Med. Chem. 2016, 16, 1200-1216. [CrossRef]

9. Aben, O.; Jhimli, B. Sulfonamide drugs: Structure, antibacterial property, toxicity, and biophysical interactions. Biophys. Rev. 2021, 13, 259-272.

10. Peng, J.; Wang, K.; Feng, T.; Zhang, H.; Li, X.; Qi, Z. The effect of (1S,2R-((3-bromophenethyl)amino)-N-(4-chloro-2trifluoromethylphenyl) cyclohexane-1-sulfonamide) on Botrytis cinerea through the membrane damage mechanism. Molecules 2020, 25, 94. [CrossRef]

11. Gang, F.; Li, X.; Yang, C.; Han, L.; Qian, H.; Wei, S.; Wu, W.; Zhang, J. Synthesis and insecticidal activity evaluation of virtually screened phenylsulfonamides. J. Agric. Food Chem. 2020, 68, 11665-11671. [CrossRef]

12. Chen, T.; Li, W.-Q.; Liu, Z.; Jiang, W.; Liu, T.; Yang, Q.; Zhu, X.-L.; Yang, G.-F. Discovery of biphenyl-sulfonamides as novel $\beta-\mathrm{N}$-acetyl-D-hexosaminidase inhibitors via structure-based virtual screening. J. Agric. Food Chem. 2021, 69, 12039-12047. [CrossRef]

13. Sharma, P.; Awasthi, P. Synthesis, characterization, in vivo, molecular docking, ADMET and HOMO-LUMO study of Juvenile hormone analogues having sulfonamide feature as an insect growth regulators. J. Mol. Struct. 2021, 1231, 129945. [CrossRef]

14. Available online: http://www.chinapesticide.org.cn/hysj/index.jhtm (accessed on 18 January 2022).

15. Li, X.; Wu, D.-C.; Qi, Z.-Q.; Li, X.-W.; Gu, Z.-M.; Wei, S.-H.; Zhang, Y.; Wang, Y.-Z.; Ji, M.-S. Synthesis, fungicidal activity, and structure-activity relationship of 2-oxo- and 2-hydroxycycloalkylsulfonamides. J. Agric. Food Chem. 2010, 58, 11384-11389. [CrossRef]

16. Wang, M.; Du, Y.; Liu, C.; Yang, X.; Qin, P.; Qi, Z.; Ji, M.; Li, X. Development of novel 2-substituted acylaminoethylsulfonamide derivatives as fungicides against Botrytis cinerea. Bioorg. Chem. 2019, 87, 56-69. [CrossRef]

17. Liu, C.-H.; Chen, X.-Y.; Qin, P.-W.; Qi, Z.-Q.; Ji, M.-S.; Liu, X.-Y.; Babu, P.V.; LI, X.-H.; Cui, Z.-N. Synthesis, fungicidal activity, and structure activity relationship of $\beta$-acylaminocycloalkylsulfonamides against Botrytis cinerea. Sci. Rep. 2017, 7, 42096. [CrossRef]

18. Li, X.H.; Yang, X.L.; Liang, X.M.; Kai, Z.P.; Yuan, H.Z.; Yuan, D.K.; Zhang, J.J.; Wang, R.Q.; Ran, F.X.; Qi, S.H.; et al. Synthesis and biological activities of 2-oxocycloalkylsulfonamides. Bioorg. Med. Chem. 2008, 16, 4538-4544. [CrossRef]

19. Li, X.H.; Ji, M.S.; Qi, Z.Q.; Li, X.W.; Shen, Y.X.; Gu, Z.M.; Zhang, Y.; Wei, S.S.; Wang, Y.Z.; Wang, D.Q. Synthesis of 2-amino-6oxocyclohexenyl-sulfonamides and their activity against Botrytis cinerea. Pest Manag. Sci. 2011, 67, 986-992. [CrossRef]

20. Yang, H.Y.; Yan, X.J.; Yuan, H.Z.; Liang, X.M.; Zhang, J.J.; Wang, D.Q. Synthesis and fungicidal activity of 2-oxocyclohexylsulfonamides containing fluorine. Chin. J. Pestic. Sci. 2010, 12, 449-452.

21. Wang, D.Q.; Li, X.H.; Liang, X.M.; Yang, X.L.; Chen, F.H. Preparation Method of 2-Oxocycloalkylsulfonamides and Its Usage as A Fungicide. Patent CN 200510085408.4, 24 January 2007.

22. Wang, K.; Chen, H.; Lin, Z.-G.; Niu, Q.-S.; Wang, Z.; Gao, F.-C.; Ji, T. Carbendazim exposure during the larval stage suppresses major royal jelly protein expression in nurse bees (Apis mellifera). Chemosphere 2021, 266, 129011. [CrossRef]

23. He, L.; Cui, K.; Li, T.; Song, Y.; Liu, N.; Mu, W.; Liu, F. Evolution of the resistance of botrytis cinerea to carbendazim and the current efficacy of carbendazim against gray mold after long-term discontinuation. Plant Dis. 2020, 104, 1647-1653. [CrossRef] [PubMed]

24. Fujimura, M.; Kamakura, T.; Yamaguchi, I. Action mechanism of diethofencarb to a benzimidazole-resistant mutant in Neurospora crassa. J. Pest. Sci. 1992, 17, 237-242. [CrossRef] 
25. Sun, H.-Y.; Wang, H.-C.; Chen, Y.; Li, H.-X.; Chen, C.-C.; Zhou, M.-G. Multiple resistance of Botrytis cinerea from vegetable crops to carbendazim, diethofencarb, procymidone, and pyrimethanil in China. Plant Dis. 2010, 94, 551-556. [CrossRef]

26. Berg, C.; Hill, M.; Bonetti, C.; Mitchell, G.C.; Sharma, B. The effects of iprodione fungicide on survival, behavior, and brood development of honeybees (Apis mellifera L.) after one foliar application during flowering on mustard. Environ. Toxicol. Chem. 2018, 37, 3086-3094. [CrossRef]

27. Krause, C.R.; Weidensaul, T.C. Ultrastructural effects of ozone on the host-parasite relationship of Botrytis cinerea and Pelargonium hortorum. Phytopathology 1978, 68, 301-307. [CrossRef]

28. Feio, S.S.; Franca, S.; Silva, A.M.; Gigante, B.; Roseiro, J.C.; Marcelo Curto, M.J. Antimicrobial activity of methyl cis-7-oxo deisopropyldehydroabietate on Botrytis cinerea and Lophodermium seditiosum: Ultrastructural observations by transmission electron microscopy. J. Appl. Microbiol. 2002, 93, 765-771. [CrossRef]

29. Wessels, J.G.H. Tansley Review No. 45 Wall growth, protein excretion and morphogenesis in fungi. New Phytol. 1993, 123, 397-413. [CrossRef]

30. Kang, Z.; Huang, L.; Krieg, U.; Mauler-Machnik, A.; Buchenauer, H. Effects of tebuconazole on morphology, structure, cell wall components and trichothecene production of Fusarium culmorum in vitro. Pest Manag. Sci. 2001, 57, 491-500. [CrossRef]

31. Vesentini, D.; Steward, D.; Singh, A.P.; Ball, R.; Daniel, G.; Franich, R. Chitosan-mediated changes in cell wall composition, morphology and ultrastructure in two wood-inhabiting fungi. Mycol. Res. 2007, 111, 875-890. [CrossRef]

32. Debono, M.; Gordee, R.S. Antibiotics that Inhibit Fungal Cell Wall Development. Annu. Rev. Microbiol. 1994, 48, 471-497. [CrossRef]

33. Bracker, C.E. Ultrastructure of Fungi. Annu. Rev. Phytopathol. 1967, 5, 343-372. [CrossRef]

34. Yoshida, M.; Yukimoto, M. Effects of Fungicides on Channels in the Fungal Membrane. Pestic. Biochem. Phys. 1993, 47, 171-177. [CrossRef]

35. Yan, X.; Liang, X.; Wang, D. Primary mode of action of novel fungicide chesulfamide against Botrytis cinerea. Abstr. Pap. Am. Chem. Soc. 2014, 248, 1001-AGRO.

36. Li, Y.; Cai, Y.; Liang, Y.; Ji, P.; Xu, L. Assessment of antifungal activities of a biocontrol bacterium BA17 for managing postharvest gray mold of green bean caused by Botrytis cinerea. Postharvest Biol. Technol. 2020, 161, 111086. [CrossRef]

37. Huang, J.X.; Liang, X.M.; Zhang, J.J.; Yan, X.J.; Dong, Y.H.; Li, C.S.; Zhang, L.P.; Xu, Z.T.; Li, L.; Yuan, H.Z.; et al. Fungicidal activity of 12-propoxyimino-1,15-pentadecanlactam on selected crops. Crop Prot. 2009, 28, 947-951. [CrossRef]

38. Standardization Administration of the People's Republic of China. Pesticide-Guidelines for the Field Efficacy Trials (I)-Fungicides against Gray Mold of Vegetables; Standard No. GB/T 17980.28-2000, 01 February 2000; Standardization Administration of the People's Republic of China: Beijing, China, 2000. 